\title{
Analog Rice Made From Cassava Flour, Corn and Taro for Food Diversification
}

\author{
Isti Pudjihastuti ${ }^{1 *}$, Siswo Sumardiono ${ }^{2}$, Edy Supriyo $^{1}$, and Heny Kusumayanti ${ }^{1}$ \\ ${ }^{1}$ Industrial Engineering Technology Vocational School Diponegoro University, Indonesia, \\ ${ }^{2}$ Chemical Engineering Department, Faculty of Engineering, Diponegoro University, Semarang, Central Java, Indonesia
}

\begin{abstract}
Paddy rice and rice are the staple foods of the people in Asian region, especially Indonesia. This plant was developed from seeds, developing varieties, planting methods to cooking methods. Without changing preparation at the household level to get better results. Analog rice is one of the nutritious instant food products that has successfully developed. Analog rice is one solution that can be developed in overcoming the availability of food both in terms of the use and application of new food sources (food diversification). Analog rice is a processed product that uses non-rice ingredients or mixes with rice that resembles rice. Non-rice ingredients can use cereal or tubers or mix some ingredients. Analog rice is a substitute for rice in general by using plants that are widely grown in Indonesia, thereby reducing dependence on rice. The purpose of this study was to find the optimal mix composition of cassava flour, corn and taro to produce analog rice and to know the physicochemical properties of analog rice which could replace paddy rice. The results showed that the best analog rice had $128.4 \%$ water absorption, $12.51 \%$ water content, $71.94 \%$ carbohydrate, $8.5 \%$ protein, $1.1 \%$ fat and $14.09 \%$ amylose content included in low amylose rice.
\end{abstract}

Keywords: physicochemical; characteristics; engineering; taro.

\section{Introduction}

In addition to rice, Indonesia also has other local food sources such as corn, sorghum, cassava, sweet potatoes, sago, and others. However, non-rice foodstuffs are currently relatively low. The aspect of availability of tubers can be an alternative in fulfilling food. As a material that contains high carbohydrates [1]. The advantages of rice in its abundant availability, easy to find and easy processing make it difficult for people to divert their consumption to other non-rice food sources. In order for the food diversification program to be carried out to reduce the level of rice consumption, the local non-rice food source must be processed in such a way that it has characteristics such as rice, both physical properties of grain, delivery, and texture. Rice products made from non-rice ingredients are known as analog rice [2]. Analog rice is one of the diversifications of food made from various kinds of flour which can be an alternative food substitute for rice from rice [3]. Efforts to use analog rice can prevent various degenerative diseases, by designing analog rice formulas in order to have antioxidant content. Corn has beta carotene in addition to functioning as provitamin $\mathrm{A}$, it is also widely reported to function as a natural antioxidant, can increase body immunity, and inhibit degenerative damage to cells by counteracting free radicals [4-6].

The method of making analog rice consists of two ways, namely granulation and extrusion methods. The difference between the two methods is the dough gelatinization stage and the printing stage. The difference in these methods causes differences in the final shape of the product. The results of the granulation method are granular, while the results of the extrusion mold are oval and resemble rice. The advantages of extrusion technology, the high production capacity of extruder equipment so that it can mass produce products [7]. In making analog rice the process uses extruders with cold extrusion process technology or hot extrusion, this process depends on the material and desired results [8]. Food extrusion technology is the process of flowing a composition of food raw materials through a barrel by pressing using a screw with speed variations so that mixing and heating occur either due to friction or heating from the heater, then passing the mold designed to form and/or develop extrusion results such as rice and cutting to the desired size [9]. After the product comes out of the die, the cutting tool will automatically spin and cut the product so that the final product will have a shape like rice.

The purpose of this study was to find the optimal composition of the mixture of cassava flour, corn and taro to produce analog rice which could replace the function of rice; know the physical/characteristic properties of analog rice. Knowing the organoleptic properties of analog rice and knowing the composition of water and the duration of rice from analog rice to produce analog rice with the best quality.

\footnotetext{
* Corresponding author: istipudjihastuti@gmail.com
} 


\section{Materials and Methods}

The materials used in this study were cassava flour (cassava), corn flour, taro flour with various mixed formulations. Steps in making flour:

Making mocaf flour (Modified Cassava Flour) by peeling and washing cassava until the impurities that are attached are gone, cutting wood, with thin pieces so that the drying process can take place quickly. After that, the cut cassava was fermented with lactic acid bacteria for 57 days, cassava dried in an oven at $60^{\circ} \mathrm{C}$ for 12 hours to dry, the dried cassava was then ground into flour and sifted with 80 mesh sieves [10].

Making Taro Flour is done by peeling and washing the taro clean of dirt, cutting thin taro with a thickness of $1-2 \mathrm{~cm}$, the taro is steamed for 10 minutes at $90^{\circ} \mathrm{C}$, soaking in a $15 \%$ salt solution overnight, taro washed and soaked again with a solution of rice straw ash in comparison (1 kg of taro, 10 grams of ash, 1 liter of water) for one night. Then the taro is washed clean and then dried at $60^{\circ} \mathrm{C}$ for 7 hours. The dried taro is then ground into taro flour and sieved with an 80 mesh sieve [11].

Making corn flour is done by the process of adding water which consists of several stages, namely corn shelling, followed by the destruction of corn kernels using a blender to grits, separation from the institution, added water with a ratio of 1: 1 , then stored for one night in plastic, grits then milled and dried in an oven at $50^{\circ} \mathrm{C}$, after drying, then corn flour is sifted using an 80 mesh sieve [7],

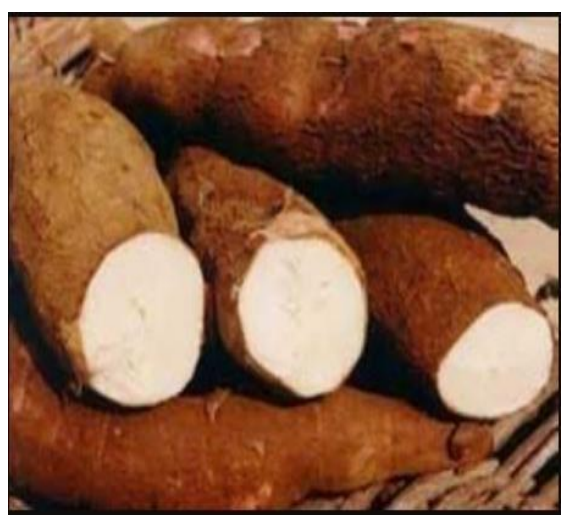

Fig. 1. Cassava

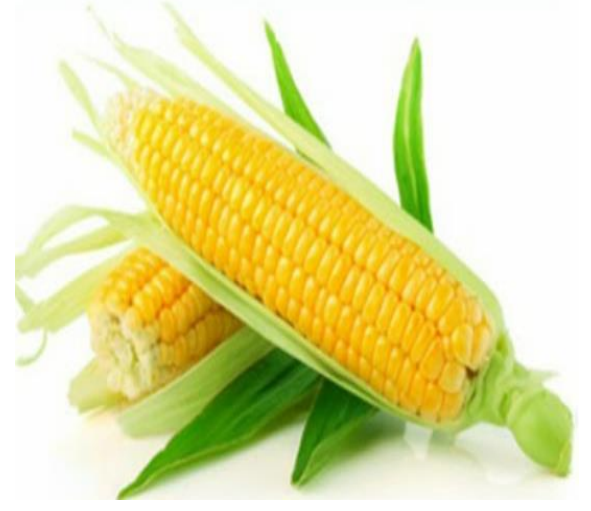

Fig. 2. Corn

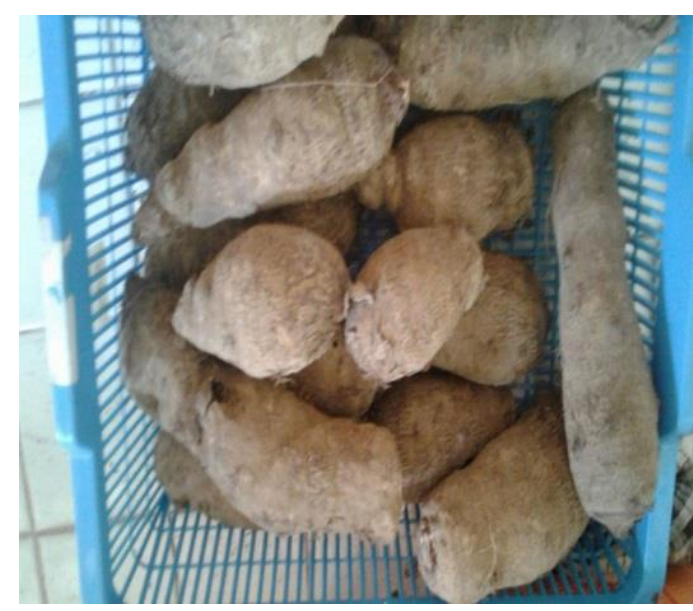

Fig. 3. Taro

Table 1. Analog Rice Formulations

\begin{tabular}{|c|c|c|c|c|}
\hline Formula & Unit & T Cassava & T Corn & T Taro \\
\hline 1 & $\%$ & 60 & 30 & 10 \\
\hline 2 & $\%$ & 55 & 30 & 15 \\
\hline 3 & $\%$ & 50 & 35 & 15 \\
\hline 4 & $\%$ & 45 & 35 & 20 \\
\hline 5 & $\%$ & 40 & 40 & 20 \\
\hline 6 & $\%$ & 35 & 40 & 25 \\
\hline 7 & $\%$ & 30 & 45 & 25 \\
\hline
\end{tabular}

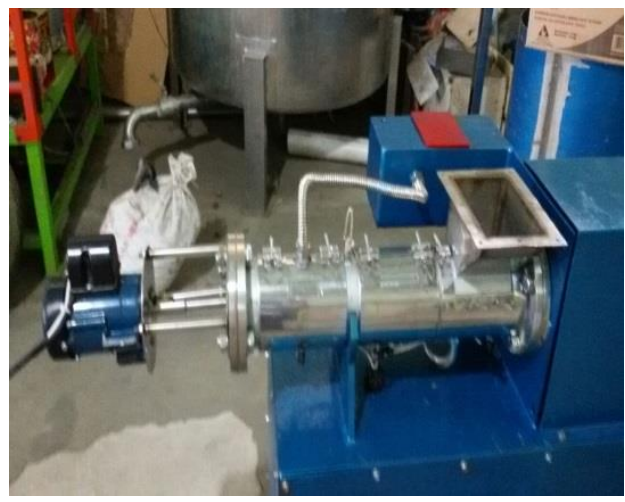

Fig. 4. Extruder

The stage of making rice is analogous by mixing cassava flour, taro flour, corn flour and other analysis materials such as skim milk, water, and emulsifying agent mixtures using a mixer with comparisons according to the variables as shown in Table 1 . The precondition stage is carried out, where flour is formulated with rice the analogue is maintained in steamed conditions at a temperature of $80-90^{\circ} \mathrm{C}$ and wet for 20 minutes. While at the stage of making analog rice, it is done by inserting composite flour mixture, skim milk, and other analysis ingredients into the extruder. Adjust the varying temperature of extruder $60^{\circ} \mathrm{C}, 70^{\circ} \mathrm{C}$, and $80^{\circ} \mathrm{C}$. Dry the rice grains analogously into the dryer.

Water content is one of the critical parameters in the extrusion process. Increased water content in the precondition and extrusion process will increase the water content in the dough so that the viscosity of the dough will decrease or plasticization occurs. 


\section{Results and Discussion}

In this study analog rice production uses raw materials of cassava flour, corn flour, and taro flour. The third flour that will be used is analyzed first the carbohydrate, protein and crude fiber content.

Components that have an important role are carbohydrates. Carbohydrate content in cassava flour is $85-88 \%$ [12]. According to the Directorate of Nutrition, Ministry of Health of the Republic of Indonesia (1996) carbohydrates in corn flour are $85.8 \%$; while carbohydrates in taro are $84 \%$ according to Richana (2012). The difference between the results of the analysis with the literature is due to the different types of cassava, corn and taro, all of which are influenced by the variety and age of harvest of the three.

The results of the analysis of analog rice water content ranged from 12.32 to $13.35 \%$. This water content approaches the water content of pandanwangi rice $(12.43 \%)$. The results of the water content of artificial rice in various compositions have met the water content requirements set by SNI 01-6128-2008, with a maximum content of $14 \%$. This number is a safe water content for storing rice, which is $<14 \%$ (weight). With water content $<14 \%$ (ww) will prevent the growth of fungi that often live in cereals/grains (Widara, 2012). The results of the analysis of the levels of analog rice proteins in various compositions ranged from $4.27 \%$ to $8.25 \%$ (dw).

The protein content produced was able to match the protein levels in pandanwangi rice by $8.4 \%$. The analysis of analog rice fat in various compositions ranges from $0.95 \%-2.15 \%$. The fat content in various compositions is still under pandanwangi rice. The results of the analysis of the levels of artificial carbohydrates in various compositions range from $65-80 \%$. When compared with pandanwangi rice, $77.11 \%$, analogous carbohydrate content of analogue rice resembles rice in the market.

Table 2. Results of proximate analysis of cassava flour, corn and taro

\begin{tabular}{|l|c|c|c|c|}
\hline $\begin{array}{c}\text { Analysis of } \\
\text { Raw Material }\end{array}$ & Unit & $\begin{array}{c}\text { Flour } \\
\text { Cassava }\end{array}$ & $\begin{array}{c}\text { Flour } \\
\text { Corn }\end{array}$ & $\begin{array}{c}\text { Flour } \\
\text { Taro }\end{array}$ \\
\hline Carbohydrate & $\%$ & 86.0 & 64.5 & 79.6 \\
\hline Protein & $\%$ & 1.5 & 0.62 & 1.3 \\
\hline Coarse fiber & $\%$ & 3.0 & 0.01 & 2.15 \\
\hline
\end{tabular}

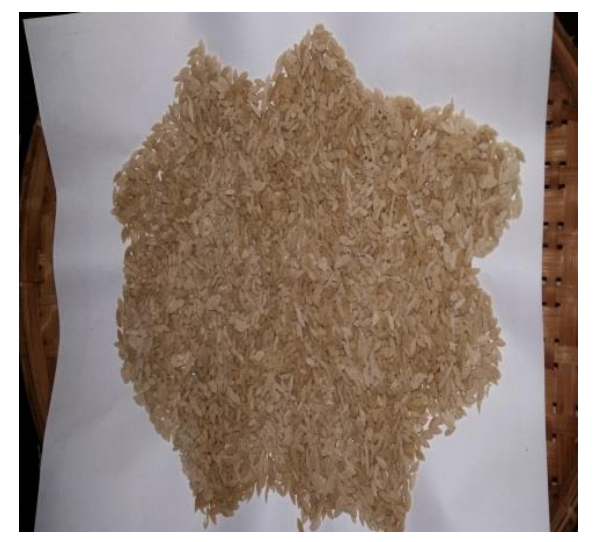

Fig. 5. Analog rice
Amylose content is one of the chemical properties that determine the physical properties of rice. Based on the analysis, artificial rice has amylose content ranging from $15.55-17.35 \%$. From the results obtained, the analog rice produced is included in rice which has low amylose, so that the rice produced when cooked will produce sticky rice, difficult to expand, clot when cold and have a shiny appearance. Public taste does not depend entirely on amylose content as a reference for favorite rice [7].

Absorption of rice from artificial rice between 1.28 1.97 times. Rice in Indonesia has average water absorption of 2.5 times, the absorption rate of water is proportional to the water requirement when cooking rice. The higher the absorption rate, the more water needs when cooking rice. The level of analog rice water absorption is lower than ordinary rice. The testing of the overall hydonic level needs further analysis to determine the best formulation. In overall hedonic testing, analog rice with the highest value is found in formula 3 . The overall assessment is based on color, texture, and taste of analog rice. In analog rice formula 3 has a bright color with a brightness of 80.43 , higher than rice control, namely pandanwangi rice of 72.57 . The carbohydrate content of artificial rice is 71.94 lower than pandanwangi rice. However, artificial rice protein levels amounted to 8.5 excesses of pandanwangi.

\section{Conclusion}

Research results obtained the best analog rice with formula 3, has a bright color with a brightness of 80.43 and has a water absorption capacity of $128.4 \%$. From the results of chemical analysis tests to determine the content of analog rice results, in this study, the best results were obtained with a water content of $12.51 \%$, $71.94 \%$ carbohydrates, $8.5 \%$ protein and $1.1 \%$ fat. Amylose analogue rice content was $14.09 \%$, thus it was categorized as low amylose rice.

\section{Acknowledgement}

Thanking you for the DRPM for funding this research in the PTUPT scheme.

\section{References}

1. N. Richana, T.C. Sunarti, The Characterization of Physicochemical Properties of Starch and Flour Starch From Canna Tuber, Suweg, Coconut Yam, and Gembili, J. Pascapanen 1(1), 29-37 (2004)

2. M. Machmur, D. Dharulsyah, M.H. Sawit, A. Subagyo, R.B, Food Diversification The Right Solution to Building National Food Security, Jakarta: Badan Ketahanan Pangan Kementerian Pertanian (2011)

3. M.Y. Samad, Making Artificial Rice with Raw Materials of Cassava and Sagu, J. Sains dan Teknol. 2(1), 36-40 (2003)

4. M. Kurniawati, The Stabilization of Bran and Its Application to Analog Rice, Thesis IPB (2013) 
5. S.T. Mayne, Beta Carotene, Carotenoids and Disease Prevention in Human, FASEB Journal 10, 690-670 (1996)

6. L.G. Hongmin, Xiaoding, M. Daifu, Orange-Flesh Sweetpotato, a Potential Source for Beta - Karoten Production, In E.T. Rasco, V.R. Amante. (eds). Sweet Potato. Manila: ASPRAD (1996)

7. S.S. Widara, S. Budijanto, Study of Rice Analogue Production from Various Carbohydrate Sources Using Hot Extrusion Technology, Fakultas Teknologi Pertanian. Institusi Pertanian Bogor (2012)

8. M.N. Riaz, Extruders in Food Applications, Boca Raton, United States of America: CRC press (2000)

9. J.L. Rossen, R.C. Miller, Food Extrusion, Food Technol. 27(8), 46 (1973)

10. K.A. Buckle, R.A. Edwards, G.H. Fleet, M. Wotton, Food Science, University of Indonesia Press. Jakarta (1987)

11. R.D. Prameswari, T. Estiasih, Utilization of Gembili Flour (Dioscorea esculenta L.) in the Use of Cookies, Jurnal Pangan dan Agroindustri 1(1) (2013)

12. S. Widowati, Utilization of Byproducts of Rice Milling in Supporting Rural Agro-Industry Systems, Bul. Agrobio 4(1), 33-38 (2001) 